ten thousand represents the absolutely poor who now live under the most unhygienic conditions; but before dying they will have eost the community four nillion two hundred and thirty-four thousand dollars."

('To be continued.)

\title{
WHAT THE SUPERINTENDENT GETS IN HER MAILS
}

\author{
By MARY AgNeS SNIVELY \\ Superintendent of Surses Toronto (ienernl Hospital
}

In reading a cop! of the Ladies' Home Jourmal not long ago uy cye caught these words, "What the President Gets in Ilis Mitil." 'This led me to think that possibly some of the readers of l'ine Amsricas Jounnal of Nersing might care to know something about the exacting and unremunerated duties which confront the superintendent of a hospital in her position as publie servant, consequently a few specimen letters, all of which are genuine, nre appended:

Mr. A., chairman of the Hospital Board of Trusts, writs: "We are just now on the subject of hospital furnishing, and know you are nn cnthusiast on that subject. Would you mind sending me a list of neeessary kitehen articles, from an egg-heater to a kitchen range?"

Mr. B. sends a printed list of questions to be unswered eorering n page of foolseap, beginning with: "What kinds of beds have you in your public wards? Kinds of springs and mattresses? Cost and where olstainable?" and ending with: "How do you manage as to patients sent from outside the eity, also eity patients? Who pays? Is surgery included? How is your medical stnff appointed, also consultants?"

Miss C. has just aceepted a hospital position and wonld like a complete list of articles necessary for a private room. Would like an estimate regarding number of sheets, pillow-eases, towels, etc., as wcll as china and cutlery, and the probable cost for furnishing sneh a room. She cncloses a list of articles for a publie ward with the request that this be corrected or ruvised.

Dr. I. has opened a private hospital and wishes to secure a head nursc possessed of every possible qualification and virtue, and states that he is prepared to offer a salary of fifteen dollars per month, with board, room, and laundry included, but rather than not get the right sort of woman he would be willing to go as high us twenty dollars per month, provided she enue three montlis on trial.

A perplexed superintendent of nurses states her troubles thus: "I am writing youl regarding matters of diseipline in conneetion with train- 
ing-sehools and would like to know: When nurses are off duty are they allowed to see gentlemen friends at their home? Are they allowed to meet gentlemen outside and aeept their eompany as far as the residenee? What is your general rule regarding the company and movements of nurses when off duty? I think nurses are a great bother anywaly; they are always wanting sonething or other. Hospital life at best is an uneertain condition, and one never knows when matters may arise which may so involve the management that the honest efforts of the superintendent niay be misunderstood, and her influence unay be neutralized if not altogether destroyed."

$\Lambda$ literary lady wants to place a little matter before the superintendent which she explains as follows: "Our little village was without a publie library, so, in order to raise funds for this purpose, we deeided upon a 'Japanese tea.' For the sum of fifteen eents the purchaser was provided with a niee eup of tea, and was allowed to beeome the possessor of the colp and saneer in which it was served. 1 was ehosen by the Ladies' Committee to purehase the requisite number of enps and saueers, and in doing this I overestimated the number required by about six dozen. 'The 'tea' was a sueess, but I an now in the very unpleasant position of laving this large number of eups and sancers on my hands, and as everyboly in the village has already bought one, it is not possible to dispose of any more here. The thought oeenrred to ne that possibly yon might manage to sell them to the nurses in your sehool. I know nurses are generally fond of laving pretty eups and saueers in their rooms, and these they could have at a lower eost than they are selling for down town. Kindly let me hear from you at once, as this is a matter of great importance to nue."

On a partienlarly busy morning an enthusiastic young woman is ushered into the offiec. She greets the superintendent gushingly, telling hor she has made np) her mind to enter a hospital. (She expects this remurk to make a profound impression.) She proeeeds: "I want you to tell nue if you think I will make a good nurse. I'll like to be sure on that point, for I would not like to fail, yon know. I've had my head examined and the plirenologist said I was adapted for nursing, and when motlier was ill the doetor said to me, 'Why don't you go into a trainingschiool?" I think l'll go to New York, but I have coune to ask your advice about the different scllools, and I want you to give me some addresses in l'hiladelphia and Boston as well, with your private opinion regarding the relative merits of these sehools."

The door eloses, and as the young lady disappears a niddle-aged woman is slown in, loringing with her a daughter aged sixteen years. The mother looks about in a frightened way, to be assured she is alone 
with the superintendent, then asks distractedly, "Are you the matron of the Lying-in State Hospital ?"

The superintendent, alone once more, turns to her morning mail, and finds a note from an editorial friend requesting an article for the next issue of his periodical entitled “ A Nurse's Duties in a Hospital from Early Morn till Dewy Eve."

A sceond letter reads: "Have you anyone with you whom you could recommend as being able and willing to take a situation in the country? Our house is large, and I want a girl or woman able to clean floors, wash, iron, and do gencral plain cooking, able to assist in milking if necessary. Must be careful, elean, and nice-mannered, an able woman for general work in a country place. My work is not heavy country work, but I am particular, and want it done well and clean."

The third one is still more interesting: " Dcar Madam, I don't know your name; however, I want you to tell all the nurses that you have heard from me, and that I want them to write to me, for I dearly love them all, and you too, whether I know you or not. I have found the dear, kind nurses to be loving and obliging, and I know how glad the poor, suffering patients were to get a paper to read to help to take their thoughts off their pain, and I now think I have got a lovely magazine that cveryone can afford to take. It eosts only twelve cents a year. It eontains over thirty pages, stories and faney work, and recipes and fashions. I want you to please tell the patients about it. They can lave it sent to the hospital or to their own homes. Please try and get all you can and send them to me by the 2ith of this month. I will reward you for your trouble. Excuse this scriblbling. but I am doing this for the sake of some poor patient. I hope this will eatch some of the dear nurses."

\title{
HYGIENE OF THE HOUSEHOLD
}

\author{
BY JEVILFEN HARRISON \\ Graduate Post-Graluate HospitaJ, New York \\ (Continued from page 432)
}

IT may appear to the "initiated" that I have entered orermuch into the details of the preparation for a surgical operation, but my department is dedicated more espeeially to the requirements of the "home nurses,"-viz., mombers of the family who are often called upon in the absence of a trained nurse to supply her place as far as lies in their power.

I am well aware that it would be diffieult-I might say impossible- 